\title{
The Amphipoda collected by the "Huxley" from the North Side of the Bay of Biscay in August, 1906.
}

By

\author{
E. W. Sexton.
}

\section{WITH PLATE III.}

THe Amphipoda dealt with in this paper were collected in August, 1906, by Dr. Allen, to whom I am indebted for the opportunity of examining them.

The collection contained thirty-five species (belonging to twenty families), of which one only, Tryphosites alleni, is new to science. Five others, Stenothoe richardi, Syrrhoites walkeri, Syrrhoe affinis, Eusirus biscayensis, and Rhachotropis rostrata, are recorded for the first time since their original discovery. The geographical range of five species has been considerably extended, viz. Syrrhoe affinis, Tmetonyx similis, Sympleustes glaber, Epimeria parasitica, and Laetmatophilus tuberculatus; the four last forms have not been hitherto recorded with certainty south of Norway.

Several of the genera have been discussed separately in four papers which I have published elsewhere [34-37].

The classification followed is that of Stebbing in his classical monograph on the Amphipoda in Das Tierreich. Previous records of the capture of any species in the Bay of Biscay are given below the account of the species.

The measurements in all cases, unless otherwise stated, are taken from the tip of the rostrum to the tip of the telson.

Tribe GAMMARIDEA.

\section{FAM. LYSIANASSIDAE.}

Gen. Trischizostoma, Boeck.

Trischizostoma nicæense (Costa).

Station XII. One specimen, an ovigerous female, measuring $23 \mathrm{~mm}$. For synonymy and description, see Sexton (34). 
Recorded once before from the Bay of Biscay by Chevreux as Guerinella nicaensis (15).

Gen. Ichnopus, A. Costa.

Ichnopus spinicornis, Boeck.

(Stebbing, Das. Tierr., p. 52.)

Station X. Six specimens, all females, the largest measuring $13 \mathrm{~mm}$., the others small, averaging $5 \cdot 5-6 \mathrm{~mm}$. in length.

This species has been recorded before from the Bay of Biscay, trawled twice by the Hirondelle (Chevreux (14), p. 15), and once by the Britannia (Walker, (46), p. 159).

GeN. Tmetonyx, Stebbing.

Tmetonyx similis, G. O. Sars.

Station II. One specimen, an ovigerous female, measuring $18 \mathrm{~mm}$.

This specimen is a very large full-grown female, which has apparently developed the secondary sexual characters of the male. Tattersall has recorded a similar instance in his recent paper on Schizopoda (Fisheries, Ireland, Sci. Invest., 1910, II [1911], p. 16), in which a full-grown ovigerous female had assumed the rostrum characteristic of the adult male.

The Huxley specimen agrees in every particular with Sars's description and figures (30), p. 93, pl. 33, with the exception of the antennae. Sars's description of the flagella is as follows: In the superior antenna "flagellum more than twice the length of the peduncle, and composed of about twenty articulations, the first of which is rather large, about equal in length to, the four succeeding ones combined; accessory appendage scarcely attaining one-third of the length of the flagellum and six articulate. Inferior antennae but little longer than the superior, flagellum composed of about twenty-four articulations." In the specimen examined the first joint of the primary flagellum equalled in length the six following joints taken together; 19-jointed; accessory flagellum 7-jointed. The inferior antenna was twice the length of the superior; flagellum composed of 42 joints. Both pairs of antennae were calceoliferous, one calceolus on each joint, from the 5th-16th in the superior; and in the inferior from the 3rd-24th, then on alternate joints to the 30th. The calceoli do not form a continuous row, but alternate in the same way as those of the Tryphosa antennipotens figured by Stebbing in his Challenger Report, pl. 6 .

This is the first record of the species from the Bay of Biscay. 


\section{Gen. Tryphosites, G. O. Sars.}

\section{Tryphosites alleni, Sexton.}

Station XII. Two specimens, ovigerous females, measuring $10 \mathrm{~mm}$. in length.

For description and figures see (37).

\section{FAM. METOPIDAE.}

\section{Gen. Proboloides, Della Valle.}

Proboloides gregarius (G. O. Sars).

(Stebbing (41), p. 189.)

Station XIII. One specimen, an ovigerous female, $5 \mathrm{~mm}$. long.

First gnathopod. The palmar margin is sharply serrated, as well as the inner edge of the finger. The finger carries a small decurrent tooth subapically, two setules inset in the notch and four others at intervals along the margin. The 4 th and 5 th joints are furnished posteriorly with strong flat dentate bristles in addition to the feathered setae, three on the 4 th joint and two on the 5 th.

Recorded once before from the Bay of Biscay by Walker (46), p. 159 .

\section{FAM. CRESSIDAE.}

Gen. Cressa, Boeck.

Cressa dubia (Bate).

(Stebbing (41), p. 191.)

Station VII. Depth, $\dot{4 \dot{4} 4}$ fathoms ; one specimen, a male, $2 \mathrm{~mm}$. long,

The previous records from the Bay of Biscay (Chevreux (13), p. 478, and (10) p. 121) are from quite shallow water, $6 \mathrm{~m}$.

\section{FAM. STENOTHOIDAE.}

GEN. Stenothoe, Dana.

Stenothoe richardi, Chevreux.

(Stebbing (41), p. 194.)

Station XIII. One specimen, a male, measuring $4.5 \mathrm{~mm}$. in length; trawled in 412 fathoms.

The only other specimen known, also a male, $5 \mathrm{~mm}$. long, was taken by the Princesse Alice (Chevreux (12), pp. 427, 432-5), in August, 1894, in this same region, to the south of Huxley Station. The method of capture was the same, the trawl; the depth recorded 1262-748 mètres. 


\section{FAM. ACANTHONOTOZOMATIDAE.}

Gen. Iphimedia, Rathke.

Iphimedia obesa, Rathke.

(Stebbing (41), p. 214.)

Station V. One specimen, nearly $12 \mathrm{~mm}$. in length, several young remaining in the pouch.

Boeck (4), p. 246, erroneously describes the maxilliped-palp as 4jointed, the 4th joint rudimentary, although in the figure (Pl. XVIII fig. $11 \mathrm{~h}$.) it is represented as 3 -jointed. Sars gives the number of joints as three, "dactylus wholly wanting" (30), p. 377. The Huxley specimen agrees with Sars's figure, except that the apex of the $3 \mathrm{rd}$ joint is truncate, not rounded. The large sensory spines on this joint are each composed of a stout feathered shaft and a small endpiece, which is inserted in the cleft at the apex of the shaft.

Recorded by Chevreux (13), p. 479, and (14) p. 63; and by Walker (46), p. 159. Chevreux's records are from much shallower water, 10-50 mètres.

\section{FAM. TRONIDAE.}

Gen. Syrrhoites, G. O. Sars.

Syrrhoites walkeri, Bonnier.

(Stebbing (41), p. 281.)

Station XII. One specimen, a large female, $9 \mathrm{~mm}$. in length.

This is the first record of the species since its discovery by the Caudan Expedition in the Gulf of Gascony, 1895.

The Huxley specimen is larger and older than the female described by Bonnier (6), pp. 647-50, measuring $9 \mathrm{~mm}$., as compared with the " un peu moins de $7 \mathrm{~mm}$." of Bonnier's largest specimen. The greater age is shown by the greater number of joints in the flagella of the antennae, Bonnier's female having nine in the superior flagellum and seven in the inferior, while the Huxley specimen has eleven and nine respectively. The incubatory lamellae are fully developed, no eggs remaining in the pouch.

GeN. Syrrhoe, Goës.

Syrrhoe affinis, Chevreux.

1908. S. affinis, Chevreux (16), pp. 7-9, fig. 4.)

Station IX. Two specimens, measuring $9.5 \mathrm{~mm}$., ovigerous females, one with eggs nearly hatched. 
The following notes may be found useful in supplementing the short account given by Chevreux :-

Bodly. Peraeon-segment 7, and pleon-segments 1-4 dorsally serrate as in $S$. papyracea Stebbing, to which it bears a strong resemblance. The number of the serrations differs in the different segments, and occasionally the number on one side of a segment differs from the number on the other side; each serration has a long fine setule inset. In peraeon-segment 7 the serrations number twenty on the right side of the prominent central tooth and eighteen on the left; they extend across the segment almost to the posterior angles, each of which is produced into a small tooth with a setule inset above. The 1st pleon-segment has twenty-five serrations, the middle one much the longest; postero-lateral angles acutely produced, as in the 2nd pleonsegment also. This latter has twenty-one serrations, the middle one again the longest; five sensory spines inset along the inferior margin of the epimera, which are much dilated anteriorly as well as posteriorly. There are eighteen dorsal serrations on the 3rd pleon-segment, the two middle ones, of unequal length, much longer than the others; the epimera are considerably dilated inferiorly, the hind margin with seventeen upturned serrations, each with a setule inset. The 4th pleonsegment has twenty-five of the serrations; while the 5th carries two or three similar serrations on either side, just above the insertion of the uropods.

Head. Strongly vaulted in front, equalling the first four peraeonsegments taken together, in length; rostrum depressed, reaching beyond the middle of the 1st joint of the antenna, sharp-edged, apex very acute; lateral corners not much produced, truncate.

Sideplate 1. Front margin lightly curved forward; front angle subacute, hind angle rounded; posterior margin produced proximally as in Sideplate 2 ; inferior margin dilated. Inferior margin of Sideplate 2 narrowed and rounded. In Sideplate 3 the truncate portion of the hind margin has a crenulate appearance owing to the insertion of four or five setules. Sideplate 5 not much produced anteriorly, expanded and rounded posteriorly. In Sideplate 6 the anterior portion is hardly developed at all; the posterior portion is greatly produced downwards with its inferior margin truncate, one serration at the posterior angle. Sideplate 7 also with one tooth posteriorly, as noted by Chevreux.

Antennae. Superior antenna. 1st joint of the peduncle thick, more than twice as broad as the succeeding joints, with a strongly upcurved apical tooth; 2nd joint nearly as long as the 1st; 3rd not quite three-quarters the length of the 2nd, all carrying ciliated hairs and setae. Primary flagellum 15-jointed, with a long sensory 
filament on alternate joints; 1st joint long, nearly equalling the 3rd joint of the peduncle in length; 2nd joint very short; 3rd joint half as long again as the $2 \mathrm{nd}$; apical joint tipped with long setae and one ciliated hair. Accessory flagellum as long as the 1st and 2nd joints of the primary taken together.

Oral parts much as in S. papyracea Stebbing.

Upper Lip (Pl. III, fig. 1) partly carinate, distal margin truncate, corners rounded and edged with microscopic spinules.

Lower Lip, outer lobes large and rounded, covered with fine hairs, with two double-tipped sensory spines on the inner margin of each, near the apex, similar to those described by Stebbing in S.papyracea; inner lobes inflated, covered with fine hairs; mandibular processēs widely divergent, and narrowed distally.

Mandibles (Pl. III, figs. 2 and 3). Right mandible, cutting-plate margin irregularly crenate, produced below into two large teeth, with one small one between them; accessory plate large, dentate, the three sharp teeth above separated from the two large rounded ones below by a transverse row of three minute sharp denticles, the uppermost tooth with a denticle at its base. In the figure the plates are laid back to show their structure, which, owing to their great curvature, it is impossible to see in the natural position. In the left mandible, the cutting-plate margin is crenate, produced below into two large rounded teeth; accessory plate with five rounded teeth, the lowest the largest. T'here are six spines in the right spine-row, two large ones covered with minute tubercles, and four slender flexible ones, feathered on both sides; eight in the left spine-row, three large and five slender; the 1st spine is falciform in both rows. Molar prominent, strongly denticulate, with a feathered seta inset posteriorly, the teeth on the posterior edge of the crown longer and sharper than those on the anterior portion, front edge sinuous.

Maxilla 1 very like $S$. papyracea. Outer plate truncate with eleven spines in two rows, seven long spines in one row, and four shorter in the other. In the row of long spines, the two innermost are finely plumose, the next three denticulate with from twelve to sixteen denticles plumose on the outer side near the tip, the two outermost spines with five and three larger denticles respectively. In the other row, the two inner spines are simple, the 3rd carries one large and two small denticles, and the 4th spine is very stout, curved, and simple. The inner plate is fringed with ten plumose setae, the apical two much shorter than the others. The palp is considerably longer than the outer plate, with both margins microscopically serrate; 1st joint short, with three setules on the outer margin; 2nd joint nearly 
three times as long as the 1st, apex truncate with four or five long spines inset, and about ten or eleven stiff setae set in pairs along the upper part of the inner margin; spines and setae very finely serrate.

Maxilla 2. Inner plate broader than the outer; the arrangement of the setae as in S. papyracea.

Maxillipeds (figs. 4 and 5). Inner plate reaching to the distal end of the 1st joint of the palp; upper margin truncate, furnished with four stout feathered spines, two curious bent spines directed inwards, and one feathered seta. The larger of these spines (fig. 4) is situated midway on the margin, the smaller one at the inner angle. Just below the smaller spine, the outer surface of the plate is deeply hollowed, and on the lower edge of this little hollow or groove stands a strong coupling spine (fig. 5). The upper half of the inner margin carries five long stout spines, set one behind the other, feathered on both sides for half their length like the spines on the upper margin. Outer plates reaching almost to the distal end of the 2nd joint of the palp, with a row of twenty-one strong flat spines, extending along the inner margin to the outer side of the rounded apex. These spines, downturned and apically dentate, increase gradually in length to the eighteenth, the remaining and outermost three are setiform. On the outer surface five or six pairs of setae are inset submarginally, and nearly the whole of the surface is covered with a furry armature of microscopic spinules. The 2nd joint of the palp is expanded on the inner side and fringed with long setae, with the fur-like spinose armature distally. The 3rd joint is much expanded on both sides, the finger thus appearing to be set in the middle of the distal margin; the whole joint is fringed with long setae, and carries a graduated row of cleft-tipped spines on the distal outer angle. The nail is more than half the length of the finger, with one setule above and two below.

Gnathopod 1 (Pl. III, figs. 6 and 7), 2nd joint long, lightly curved, carrying six to eight extremely long and delicate plumose setae posteriorly. These setae are sparsely plumose, the feathering being very long and fine; similar setae are found on the basal joints of Gnathopod 2, and peraeopods 1 and 2. The 3rd joint has one of these setae at the distal angle. 5th joint with the anterior margin fully twice as long as the anterior margin of the 6 th; posteriorly it is a little expanded, covered with the fur-like spinose armature, and furnished with several densely crowded rows of spines on the margin; one row directed forward of small coarsely dentate spines, one row of small spines, another row of medium-sized, and a row of long cleft-tipped ones similar to the one figured (fig. 6). There appears to 
be another row beyond this of the medium-sized, and in addition three long fine, thread-like setae are found near the distal end, the longest being nearest to the hand and much exceeding it in length. The hand widens a little distally, hind margin pectinate; palm slightly oblique, fringed with long setae, and carrying at the palmar angle, besides the very large palmar spine, a group of five long spines, the apical flagella of which are of great length. The finger is a little longer than the palm, and crosses the palmar spine. For the construction of finger and spine, see fig. 7 .

Gnathopod 2, 5th joint very slender, considerably more than twice as long as the 6th, furnished on the distal posterior margin with dense rows of setae. The setae appear to be arranged in groups set closely together along the margin, each group containing four graduated setae. The hand widens distally; it resembles that of Gnathopod 1 in the construction of the finger and palmar spine and in the arrangement of the long setae on the palm. The branchial vesicles are large, as iong as the basal joint; incubatory lamellae large and wide, exceeding the basal joint in length.

Perceopods 1 and 2, practically subequal in length; branchial vesicles large, incubatory lamellae long and narrow. 2nd joint very long and slender, with long plumose setae on both sides; 4th, 5th, and 6 th joints subequal, fringed posteriorly with long fine setae; 6th joint with a stout spine and a dense fringe of these setae distally, almost concealing the finger, and exceeding it in length. The finger, as in all the peraeopods, has a long nail, both finger and nail pectinate along the outer curve; with two setules inset close to the nail, and one long plumose seta proximally on the outer margin. In peraeopod 2 the 5 th and 6 th joints have the anterior margin strongly pectinate.

Percceopod 3, 2nd joint almost circular, one setiform spine and five short stout ones on the lower part of the anterior margin, nine deep serrations posteriorly; 4 th, 5 th, and 6 th joints increase rapidly in length and decrease in thickness, all furnished with long sensory spines some of which are remarkable for the extraordinary length of their apical filaments. Another variety of spine peculiar to this peraeopod is to be found on the posterior margins of the 5th and 6 th joints, eight on the 5th and seven on the 6th, each inset with a small long-filamented spine; the shaft is laminar, and the apex of the spine is produced to nearly the length of the apical filament (Plate III, fig. 8). The branchial vesicle and incubatory lamella are small, the hairs on the latter very long.

Peracopod 4, 2nd joint large, rounded, more produced posteriorly than in Peraeopod 3; two setiform and six short stout spines anteriorly, 
ten serrations posteriorly. 5th joint half as long again as the 4 th; 6 th much longer than the 5th; finger not quite one-third the length of the 6 th. The spines on the 4 th joint are the longest, those of the 6 th the shortest and most numerous; the apical filaments of all the spines are very long, but do not reach the remarkable length of those of the 3rd peraeopod.

Percueopod 5, as Chevreux describes it; 2nd joint longer than broad, six setiform and six short spines anteriorly, thirteen serrations posteriorly. The setae as in Peraeopod 4.

Pleopods. The rami in all three pleopods are about twice as long as the peduncles; inner ramus with seventeen joints, outer ramus with eighteen; five cleft spines on the inner ramus. The coupling-spines are set in a little hollow with two long ciliated hairs; apices recurved; the upper spine has two large recurved teeth on one side, five small ones on the other; lower spine with three large and six small.

Uropod 1. Peduncle considerably longer than the outer ramus; it carries a row of seven long spines on the inner margin, six on the outer margin, the distal portion of which is produced in a long curved process reaching more than half-way down over the outer ramus. Outer ramus with three short spines on the margin, one large strong spine and two small inset at the apex. The inner rami are both broken but are evidently longer and broader than the outer. Uropod 2, outer ramus twice as long as the peduncle, inner ramus nearly four times as long. The peduncle carries two long stout spines at the outer angle. Outer ramus narrow, outer margin with three long sensory spines, inner margin with ten or eleven short stout simple spines; one broad stout spine and two small ones at the apex. Inner ramus broad and laminar; apex acutely produced: inner margin edged with a thick row of about thirty short stout simple spines; outer margin with sixteen long sensory spines inset at regular intervals. Uropod 3, badly mutilated in both specimens. Inner ramus two and a-half times longer than the peduncle; it appears to have small spines on the outer margin, and plumose setae proximally on the inner margin; both rami broad and laminar.

Telson. In the Huxley specimens the cleft is longer than Chevreux figures it. A pair of long ciliated hairs are inset on either side of the cleft near the margin, and several small flat spines are scattered over the surface proximally; the apices each with a setule in the fork.

Distribution. Taken by the Princesse Alice, $10 \mathrm{July}, 1901,33^{\circ} 59^{\prime} 30^{\prime \prime} \mathrm{N}$.; $8^{\circ} 12^{\prime} 45^{\prime \prime} \mathrm{W}$. ; trawl ; 851 mètres ; 2 females, $7 \mathrm{~mm}$. long. Chevreux (16). Taken by the Huxley, 25 August, $1906 ; 48^{\circ} 7^{\prime}$ N. ; $8^{\circ} 13^{\prime}$ W. ; Agassiz trawl ; 240 fathoms; bottom deposit, fine sand. 


\section{Fai. CALLIOPIIDAE.}

Gen. Apherusa, A. O. Walker.

Apherusa bispinosa (Sp. Bate).

(Stebbing (41), p. 305.)

Station IV. 109 fms.; 44 specimens; 30 of these were ovigerous females, $6 \cdot 5-3.75 \mathrm{~mm}$. in length.

Station X. 146 fms.; 3 specimens, 1 male and 2 females, the larger of which measured $7 \mathrm{~mm}$.

These captures are interesting as being the first authenticated records of the occurrence of this species in the open sea far from land. The depth at Station X., 146 fathoms, is the greatest hitherto recorded. A. bispinosa is generally regarded as a purely littoral or sublittoral form, and is usually found living among the algae close inshore. Sars, however, mentions (30), p. 440, "another form or variety living in somewhat greater depths," agreeing in all essential details with the littoral form, but distinguished from it by the larger size, the comparatively larger and less pigmented eyes, and the lighter hue of the body. The Huxley specimens are of this latter type. They are more slender and more spinose than the shore form.

The 3rd joint of the palp of the mandible in full-grown specimens is subequal to the 2nd in length, not shorter, as given by Sars for the shore form.

The antennae are filiform and longer than in the shore animal; the joints of the flagella very attenuated. The flagellum of the superior antenna is furnished with two sensory filaments on each of the first four joints, and two on alternate joints to the 14th in the female and to the 20th in the large males. The inferior antennae in the female are a little longer than the body ; half as long again in the male. Unfortunately all were broken; one female of $5 \mathrm{~mm}$. length had the inferior antenna $5 \mathrm{~mm}$. long, fifty-one joints in the flagellum; and a male $7 \mathrm{~mm}$. long had sixty-three joints still remaining, the broken antenna measuring $7 \cdot 5 \mathrm{~mm}$.

The proportions of the joints of the gnathopods are as given by Sars, but the hand and finger differ ( $\mathrm{Pl}$. III, fig. 9). The hand is broader, as in A. clevei Sars, with the palm oblique and subequal to the hind margin in length; the palmar margin is microscopically serrulate, with the two specialized bristles characteristic of the family, inset on either side of the finger. The finger is much longer in proportion than in the littoral form with four serrations on the inner margin in Gnathopod 1, three in Gnathopod 2. 
The postero-lateral corner in pleon-segment 1 is produced to a small acute recurved point, as mentioned by Sp. Bate (3), p. 250. In pleonsegment 3 the hind margin above the postero-lateral corner is divided into eight serrations in the large full-grown specimens, seven in the small but sexually mature animals, each serration with a setule inset; the upper tooth of the bidentate projection is very acutely produced.

All the margins of the uropods are microscopically pectinate, with the exception of the inner margin of the inner ramus of Uropod 3. The distal half of the margin of the telson is also pectinate; apex distinctly tridentate with two setules inset; two pairs of mobile sensory plumose hairs.

Previous records: By Chevreux as Halirages bispinosus (9), p. 304; as $A$. bispinosa (14), p. 70 ; and by Walker (46), pp. 158-9.

\section{FAM. PLEUSTIDAE.}

Gen. Sympleustes, Stebbing.

Three species of this genus were taken, two from deep water 412 fathoms; and one hitherto regarded as an Arctic or sub-Arctic form S. glaber from a much less depth, 75 fathoms.

\section{Sympleustes latipes (M. Sars).}

(Stebbing (41), p. 317.)

Station XIII. Three specimens, immature, measuring respectively $7 \cdot 5$, $4 \cdot 5$, and $2 \cdot 5 \mathrm{~mm}$.

Taken once before in the Bay of Biscay by the Caudan Expedition (6), p. 645 , in 1410 metres.

\section{Sympleustes grandimanus (Chevreux).}

Station XIII. Five specimens, females, 3-7.5 mm. in length.

For synonymy and discussion of this species, see Sexton (35), pp. $857-64$.

\section{Sympleustes glaber (Boeck). \\ (Stebbing (41), p. 318.)}

Station II. One specimen, a small female with ova, $4.5 \mathrm{~mm}$. in length.

This species has not been recorded before south of the Kattegat. The accessory flagellum of the superior antenna, as in other species of the genus, is quite rudimentary, 1-jointed tipped with two or three setae (cf. Sexton (35), pp. 853 and 859). 


\title{
FAM. PARAMPHITHOIDAE.
}

\author{
Gen. Epimeria, A. Costa.
}

Epimeria parasitica, M. Sars.

(Stebbing (41), p. 321.)

Station IX. Twenty specimens.

" XII. Twenty-three specimens.

This species is here recorded for the first time with certainty out of Norway. It is there found living in a semi-parasitic state on the skin of Holothuria tremula (31), p. 131, and (30) p. 367; the Huxley specimens on the other hand were taken free swimming in considerable numbers, at two stations. They are larger than the Norwegian specimens, quite half of them measuring $13 \mathrm{~mm}$. in length as compared with Sars's statement: "length of adult female scarcely exceeding $9 \mathrm{~mm}$." They appear to live at greater depths than E. cornigera. The incubatory lamellae of the females were well developed, but no eggs were found in the pouches.

\section{Epimeria cornigeria (Fabricius). \\ (Stebbing (41), p. 323.)}

Station II. Two specimens, $17 \cdot 5$ and $18 \mathrm{~mm}$. respectively.

„ V. Sixty-three specimens, average length $20 \mathrm{~mm}$; the largest measured $23.5 \mathrm{~mm}$; 11 were half-grown, and 5 small. No eggs remaining in the pouches.

„ IX. Two large specimens, mutilated.

, XI. Three specimens, largest $17 \mathrm{~mm}$.

" XII. One specimen, $22 \mathrm{~mm}$. in length.

Several previous records by Chevreux (14), p. 62, but only one or two specimens taken at a time.

\section{Fam. ATYLIDAE.}

Gen. Nototropis, A. Costa. Nototropis vedlomensis (Bate and Westwood).

(Stebbing (41), p. 331.)

Station IV. One specimen, a female, $8 \mathrm{~mm}$. in length.

The method of capture was by swab and townet attached to the dredge working at the bottom, depth 109 fathoms. Chevreux's records are from shallow water; under the name of Atylus vedlomensis as fairly common on sandy bottoms in the Bay of Croisic, 4-10 m. (9), p. 304; and as Paratylus vedlomensis at Concarneau, 15-19 m. (13), p. 480. 


\section{FAM. EUSIRIDAE.}

Gen. Eusirus, Kröyer.

Eusirus longipes, Boeck.

(Stebbing (41), p. 341.)

Station IV. Three specimens, males, the largest $8 \mathrm{~mm}$.

Previous records : Chevreux (14), pp. 65, 171, 172; and Walker (46), p. 160.

\section{Eusirus biscayensis, Bonnier.}

Station XII. Seven specimens; 6 females, $12-13.5 \mathrm{~mm}$. in length, and 1 male barely $13 \mathrm{~mm}$. long, the first hitherto recorded.

This is the first record of the species since its discovery by the Caudan Expedition. The original description was taken from a mutilated specimen. I have, therefore, redescribed and figured certain of the anatomical details (35), pp. 865-9.

\section{Gen. Rhachotropis, S. I. Smith.}

Rhachotropis helleri (Boeck).

(Stebbing (41), p. 351; and Sexton (35), pp. 869-76.)

Station XII. Twenty specimens; 1 male, $8.75 \mathrm{~mm}$. , and 19 females, $10-12 \cdot 5$ in length.

This species has been discussed and the fully developed animal figured in the above-mentioned paper.

\section{Rhachotropis rostrata, Bonnier.}

(Stebbing (41), p. 353; and Sexton (35), p. 869.

Station XII. Four specimens, males, 9-10 mm. in length.

This is the first record of the species since its discovery by the Caudan Expedition.

\section{FAM. GAMMMARIDAE. \\ Gex. Maera, Leach. \\ Maera tenuimana (Bate). \\ (Stebbing (41), p. 436.)}

Station V. One specimen, a male, $9 \mathrm{~mm}$. long.

Previous records: by Chevreux as $M$. Batei Norman and $M$. multidentata Bate (9), p. 307; and as M. Batei Norman (14), p. 83; and by Walker (46), p. 160. 


\section{FAM. PHOTIDAE.}

GeN. Leptocheirus, Zaddach.

Leptocheirus pectinatus, Norman.

$=$ Leptocheirus dellavallei, Stebbing.

(Sexton (36), pp. 576-585, Pl. XIX.)

Station II. One specimen, an ovigerous female, measuring $4.5 \mathrm{~mm}$.

For the discussion of this species and proofs of the identity of the two forms pectinatus and dellavallei, see the paper referred to above.

\section{FAM. JASSIDAE. \\ GeN. Jassa, Leach. \\ [Jassa falcata (Montagu).}

No specimens of this species were taken during the cruise, but it is necessary to include a note relating to it in order to explain my reasons for using the specific name falcata, in the discussion of J. pusilla, instead of pulchella as established by Stebbing (41), p. 654. The species is a difficult one owing to the different forms assumed by the male during development, this causing great confusion not only in the species itself, many of the stages having been described as distinct species, but also leading to further confusion with other species, pusilla in particular.

There would seem to be at least two well-marked forms of falcata. During immaturity it is absolutely impossible to distinguish between them, but as they grow they differentiate into either-a form with the flagella of the antennae swollen, some of the joints coalesced, the hand also swollen, and thumb broad; or a form with the antennae slender, joints distinct, hand and thumb slender. In both forms there appear to be two distinct kinds of adult males, besides the several markedly different stages during growth. The females are exactly alike, except that some have antennae like the first form, and others like the second. Whether these will prove to be seasonal variations, or whether they are really two distinct species, I have not as yet sufficient evidence to speak with certainty. Experiments in rearing them, commenced in 1909 in the Laboratory here, have only been successful to a certain point; some of the stages have moulted but the series is still far from complete. 
For figures of the first form see Nebeski (23), and for the second Sars (30), pl. 212; for the females Spence Bate's vuriegatus (3), p. 439, belongs to the first, pelagicus (3), p. 447, to the second form.

Through Dr. Calman's kindness I was able last year to examine in the British Museum the type specimens of Montagu's falcatus, Leach's pulchella, and Spence Bate's variegatus.

The type specimen of the species was taken by Montagu more than a hundred years ago at Torcross on the Devonshire coast. It is marked 603 a, and is referred to in the old manuscript register under that number as having been taken at Torcross. In the "List of the Specimens of Crustacea in the collection of the British Museum," 1847, by Adam White, it is entered (p. 89) as "Cerapus falcatus a. Devon (Torcross). From the collection of Col. Montagu." The specimen bears a sufficient resemblance to Montagu's drawing (22) t. 5, f. 2 , to suggest that it was the actual one from which the drawing was made. It measures $8 \mathrm{~mm}$. from the tip of the rostrum to the tip of the telson, and is of the type referred to above as the second form. The flagellum of the superior antenna has eight or nine joints, the inferior five. The second sideplate is of the form characteristic of the species, the anterior margin only half the length of the posterior margin of the preceding sideplate. The finger of the second gnathopod has a rather prominent process developed on the inner margin; this process I have found of frequent occurrence in the larger males. The small spines which are found behind the thumb process on the hind margin of the hand are represented in Montagu's figure as another process. They are naturally much more prominent in the dried specimen than in spirit specimens, owing to the shrinkage.

There are seven specimens marked "Podocerus pulchellus, Devon," in the old manuscript register, and numbered $296 \mathrm{a}-\mathrm{g}$, which appear to be Leach's types. These are exactly the same form as Montagu's. Two have lost both gnathopoda and antennae; of the others, one is a young male with the thumb half developed, and the remaining four are adult males, thumb well developed, process on inner margin of the finger small. The antennae of all were broken, excepting two superior antennae, which had about seven joints each.

The tube marked Podocerus variegatus in Spence Bate's collection, as Mr. Walker pointed out (44), p. 472, contains more than one species, several of the specimens belonging to J.pusilla. Among the falcata were two young males and two or three full-grown ovigerous females of the type referred to above as the "first form," and figured by Bate as $P$. variegatus (3), p. 439.] 
Jassa pusilla, G. O. Sars.

(Stebbing (41), pp. 655 and 739.)

Station VII. One specimen, a large ovigerous female, $55 \mathrm{~mm}$. long.

„XIII. Three specimens, 2 males, 5 and $5.5 \mathrm{~mm}$. respectively, and 1 female, $4.75 \mathrm{~mm}$.

The separation of this species from $J$. falcata (Mont.) is rendered difficult not only by their great similarity, but by the enormous range of variation found in falcata, which at a first glance suggests the possibility of pusilla being only a young stage of that species. Walker was inclined to consider them identical; he says (45), p. 314 : "If it be admitted that Amphipoda may become sexually mature before they have attained their final moult, I think these species [pusillus and Herdmani] can hardly be maintained"; and again (44), p. 473: "I am disposed to consider $P$. Herdmani and $P$. pusillus (Sars) as examples of arrested development and mere varieties of $P$. falcatus."

Sars and Stebbing, on the other hand, consider them distinct species, but, as several of the characters given by them for distinguishing the one from the other are those subject to developmental modifications, I have thought well to discuss the different points in detail.

The two most useful and constant distinguishing features will be found in the second gnathopod, viz. the second sideplate and the hand. The inferior margin of this sideplate in pusilla forms a continuous line with the margins of the 1st and 3rd sideplates, its anterior margin being as long as the posterior margin of the 1st. In falcata, on the contrary, the anterior margin is much shorter than the posterior margin of the preceding sideplate, only half the length in full-grown specimens, giving a curious and characteristic appearance to the animal, as if the head and 1st peraeon-segment were divided from the rest of the body (the coloration adding to the effect, the head of the 1st segment and sideplates being invariably darkly pigmented, and the 2nd segment and sideplates light with a few patches of pigment). This character is found even in the young in the incubatory pouch, though with them the anterior portion of the sideplate is rounded, whereas in the full-grown animal it is angular (see figs. 10 and 11 for comparison).

With regard to the second distinguishing feature, the hand, the adult male of pusilla has the apex of the thumb bifid; in the adult male of falcata it is entire; and an examination of many thousands of specimens of this latter species shows that in it the characteristic bifid form of pusilla is never met with.

General aspect. The body is more compressed in pusilla, the sideplates longer in proportion, and the peraeopods longer and more 
slender than in falcata. The cuticle is thinner, and the coloration also differs, as Sars noted when first describing the species (29), p. 112. In falcata the pigment is in dark definite bands or patches composed of stellate markings or of dots thickly crowded together, retaining its colour even after years in alcohol. The distribution of colour can be plainly seen in Montagu's specimen even now after a century. In pusilla, on the other hand, the pigment shows only as diffused indefinite transverse bands along the posterior margins of the peraeon-segments, and occasionally on the pleon-segments as well ; spirit specimens retain very little of the colour.

Size. The difference in size is given by Sars (29), p. 112, as a specific character, but, as Walker pointed out, it cannot be used as such, for though pusilla is always small, never exceeding $5-6 \mathrm{~mm}$., and falcata attains a length of 10-12 mm., yet specimens of the latter, both male and female, have been found sexually mature at $4 \mathrm{~mm}$.

Sideplates (Pl. III, figs. 10 and 11). The proportions of the sideplates are generally given as specific characters, but they cannot be relied on as such, varying as they do with the age of the animal. Stebbing gives the falcata (41), p. 654, "3rd and 4th in of considerably deeper than 2nd and 5th"; and for pusilla o "5th nearly as deep as 4th." The sideplates in this latter species are always wider and much deeper in proportion to the body than in falcata; Sideplate 2 is rounded anteriorly, considerably expanded inferiorly, and twice as wide as deep (fig. 11); the 3rd and 4 th the deepest, as wide as deep; the 5th almost as long as the 4th. In falcata the relative proportions alter with each stage of development, the only constant feature being the short anterior margin of Sideplate 2. In the young in the marsupium $2.25 \mathrm{~mm}$. long, the inferior margins of Sideplates $1-5$ are on the same level; in specimens $5-6 \mathrm{~mm}$. in length, the 3rd, 4th, and 5th are on the same level, the 1st and 2nd shorter; at $7 \mathrm{~mm}$. length, the 5 th is slightly shorter than the 4 th; while in large specimens $9 \mathrm{~mm}$. and upwards, the 1st, 2nd, and 5th are very noticeably shorter than the 3rd and 4th.

Antennae. Here again the proportions of the joints of the peduncles, and the number of joints in the flagella vary with the growth of the animal, and cannot be employed in specific distinction. The antennae in pusilla are much more slender, and the primary and accessory flagella much longer in proportion than in falcata. The joints of the primary flagellum are long and cylindrical, and the accessory flagellum is longer in proportion to the 1st joint of the primary than in the other species, equalling half the length of the 1st joint in the adult animal. The last joint of the peduncle of the inferior antenna is fringed 
with long setae. Of the Huxley specimens the two males each have five joints in the superior and five in the inferior flagella, the accessory flagellum 2-jointed, 1st joint long, narrow, and cylindrical, and the apical joint almost rudimentary. The smaller of the two females has five joints in both superior and inferior flagella. Two of the antennae of the larger animal are broken, those remaining being the superior on the left side with seven joints, and the inferior on the right side with six. Sars (30), p. 596, gives five joints for the superior and four for the inferior.

I have been able to compare the Huxley specimens with some taken by Mr. Crawshay near the Eddystone. In these, the increase in the number of the joints with growth is plainly shown. One young male, $3.75 \mathrm{~mm}$. long, with the thumb just commencing to appear on the hand of Gnath. 2, had four joints in the superior and four in the inferior flagellum; a larger specimen, $4.25 \mathrm{~mm}$., with the thumb further developed, had five in the superior and four in the inferior; two large fully adult males, $5.5 \mathrm{~mm}$., with the bifid apex to the thumb, also had five in the superior and four in the inferior. Of the females, the smallest ovigerous one, $3 \mathrm{~mm}$, had four in the superior, three in the inferior; other young ovigerous females, $4 \mathrm{~mm}$, had four joints in both superior and inferior. In the larger ones, unfortunately, the antennae were more or less broken; one had five joints in both inferior flagella; the largest, $6.5 \mathrm{~mm}$. long, had six joints on the right and five on the left superior, five joints on the left inferior; another had six joints on the right superior, four in the right and three in the left inferior.

There are two forms of antennae in both sexes in falcata. In the one form the whole of the inferior antenna is swollen, and all the proximal joints of the flagellum coalesced, so that only three joints can be traced, the long, swollen, coalesced 1st joint, a small stout joint, and a rudimentary terminal one; the accessory flagellum is 1 -jointed and swollen. Dense fascicles of plumose setae are developed on the long joint of the flagellum and on the distal portion of the last joint of the peduncle. In the other form the inferior antenna is more slender; the joints of the flagellum are distinct five or six in number, the number frequently different on one side from the other; no plumose setae are developed, but the curved sensory spines are stronger and more numerous; the accessory flagellum is 2-jointed and cylindrical. This form is certainly near pusilla, but can be easily distinguished from it; it is much more heavily built; the last joint of the peduncle lacks the fringe of long setae, being only sparsely setose; the joints of the flagellum are short and thick; and 
the sensory spines of the flagellum also show a marked difference, being short and thick, and curved like hooks, while in pusilla they are long and slender, and hardly curved at all. The fascicles of plumose setae cannot be used as a distinguishing character, seeing that it is only in certain stages of development that they occur in falcata.

Gnathopod 2. All the specimens taken by the Huxley are fully adult, the two males showing the characteristic development of the thumb. There are two forms of the hand in falcata, correlated with the two forms of antenna. In the first form the hand is broad and swollen, thumb broad and truncate at the apex. In the second form the hand long and slender, with fascicles of plumose setae along the palmar margin, and the thumb is long and narrow, tapering to a subacute point. But in all the stages of development in falcata the apical margin of the thumb is entire, with not the slightest tendency to the bifid apex of the adult pusilla. The young male of pusilla resembles the young male of the second form of falcata in the development of the thumb, cf. figures given by Sars (30), pl. 212, p. 2 , $0 \div$, and pl. 213,1 , p. 2 , $0 \div$.

Norman (27), p. 93, considers the Podocerus variegatus of Bate and Westwood (not Leach) to be the female of pusilla, but an examination of Bate's specimens in the British Museum has shown it to be the female of the first form of falcata; it has the broad, heavily-built, inferior antenna, the short stout joints in the flagellum, and the second sideplate and hand characteristic of this species.

The finger in falcata develops with age an angular projection on the inner margin, very noticeable in the full-grown male. The finger in pusilla shows no sign of it.

The Peraeopods afford another character for distinguishing the species. In pusilla they are much longer in proportion to the animal's size, and more slender, the 6th and 7th joints more elongate; 7th joint lightly curved, not falciform as in falcata; 6 th joint lacking the stout sensory spines carried by the latter species.

Distribution. J. pusilla appears to be a deep-water form, there being no authentic record of its occurrence in a less depth than 20 fathoms. $J$. falcata, on the other hand, is a littoral or sub-littoral form, building its nests in the algae and hydroids on buoys, dock-piles and rocks near the shore.

$J$. pusilla has been recorded by :-

Sars (29), p. 112, as Podocerus minutus, and (30), p. 597, as Podocerus pusillus, from the south and west coasts of Norway, and as far north as Hammerfest, " clinging to hydroidae growing in depths varying from 20-100 fathoms." 
Robertson (28), p. 27, records an amphipod as $P$. minutus taken amongst the algae on the timbers of Millport Pier, Cumbrae. I have not been able to trace his specimen, but I consider this record is open to doubt, and that in all probability he mistook a young stage of falcata for Sars's species.

Scott (32a), as Podocerus pusillus, from the Firth of Forth.

Walker (45), p. 314, as P. pusillus, off Port Erin, no depth stated.

Norman (27), p. 93, records under Bruzeliella pusilla, "two females taken at Falmouth in 1884," but as he identified these with the Podocerus variegatus of Bate and Westwood, they are therefore, as I have shown above, females of the "first form" of falcata.

Chevreux (9), p. 315, as P. minutus on Maia, dredged south-west of Belle Isle in $80-100 \mathrm{~m}$.

To these records must be added:-

Thirteen specimens taken by Mr. Crawshay, in June, 1906, $20 \mathrm{~m}$. south-west of the Eddystone, in 42 fathoms; 5 males, 8 ovigerous females; from sponge coating Inachus dorsettensis; and numerous specimens taken by Mr. Barnard, March-April, 1911, near the Eddystone, also from sponge coating Inachus.

The Huxley specimens were from very deep water; one specimen, a female, from $\frac{\dot{4} 4}{44}$ fathoms; and three specimens, 1 male and 2 females, from 412 fathoms, all full-grown animals.

\section{FAM. COROPHIIDAE.}

\section{Gen. Erichthonius, Milne-Edwards.}

Erichthonius brasiliensis (Dana).

(Stebbing (41), pp. 671 and 740.)

Station XII. 246 fathoms; 1 specimen, an ovigerous female, $6 \mathrm{~mm}$.

„XIII. 412 fathoms; 2 specimens, females, 1 measuring $5 \mathrm{~mm}$. in length, with eggs; the larger one $6 \mathrm{~mm}$., with six young ones still remaining in the marsupium; length of young, $1.25 \mathrm{~mm}$.

The greatest depth hitherto recorded for this species is given by Chevreux as 130 metres.

Previous records: by Chevreux (14), p. 108; and (9) pp. 289, 301, and 316, found on Maia squinado, trawled in 60-80 metres, as well as on algae growing on the bottom.

\section{Gev. Unciola, Say. Unciola planipes, Norman. \\ (Stebbing (41), p. 679.)}

Station IV. One specimen, an ovigerous female, $6.5 \mathrm{~mm}$. long; taken in a Low-net attached to the dredge working at the bottom.

Recorded by Chevreux (14), p. 110, from $50-180 \mathrm{~m}$. 
GEN. Siphonoecetes, Kröyer.

Siphonoecetes colletti, Boeck.

(Stebbing (41), p. 683.)

Station V. Three specimens, 2 males and 1 female of $6 \mathrm{~mm}$. length.

" IX. One specimen, a male, $5.5 \mathrm{~mm}$.

"XII. Four specimens, all males, $7 \cdot 5-8 \mathrm{~mm}$.

Previous records: by Bonnier (5), p. 347, as S. typicus Kröyer; and by Chevreux (9), p. 317, as $S$. typicus, and (14) p. 108 as $S$. colletti. The greatest depth recorded by Chevreux is 180 metres; by the Huxley at Station XII, 246 fathoms.

\section{FAM. PODOCERIDAE.}

GEN. Laetmatophilus, Bruzelius.

Laetmatophilus tuberculatus, Bruz.

1859. Laetmatophilus tuberculatus Bruzelius (8), p. 11, Taf. 1, fig. 1.

1862. Cyrtophium tuberculatum Spence Bate (2), p. 275, pl. 46, fig. 9 .

1868. Cyrtophium armatum Norman (25), p. 285.

1876. Laetmatophilus tuberculatus Boeck (4), p. 663.

\begin{tabular}{|c|c|c|}
\hline 1894. & ” & $\begin{array}{l}\text { spinosissimus } ", \quad \text { p. } 665 \text {. } \\
\text { tuberculatus Sars (30), p. } 630, \text { pl. } 226 \text {. }\end{array}$ \\
\hline & " & armatus $\quad " \quad " \quad$ p. 632, pl. 227 , fig. 1. \\
\hline & " & , $\quad$ Norman (25a), p. 493 \\
\hline & " & tuberculatus Stebbing (41), p. 696. \\
\hline & ” & armatus $\quad, \quad$ p. 697 . \\
\hline
\end{tabular}

Station XIII. One specimen, a male, $4.5 \mathrm{~mm}$. long.

This species was established by Bruzelius in 1859. In 1868 Norman described a specimen from the Shetland Isles under the name of Cyrtophium armatum. He noted its resemblance to Bruzelius's species, but considered it sufficiently distinguished from it by the following characters: "much more strongly tuberculated; and the gnathopods of different structure, the first smaller, the second larger, the hand broader and the basos spined." Sars in 1894, although he described the two species as distinct because of the peculiar armature of the body in armatus, was inclined to consider this latter form as merely a deep-sea variety of tuberculatus, giving the range of distribution as 20-50 fathoms for tuberculatus and as 50-300 fathoms for armatus.

The specimen taken by the Huxley was a large male, $4.5 \mathrm{~mm}$. in length, with the spinose armature even more accentuated than in the figure given by Sars for armatus. Through the kindness of Canon 
Norman I have been able to compare it with a Norwegian specimen of tuberculatus, also a large male, $4 \mathrm{~mm}$. in length, and as a result of this examination, I think there can be no question but that the two species are identical, armatus being the fully-developed animal.

As I have shown before (35), p. 849, the Amphipoda undergo considerable modification, even after reaching sexual maturity, the characters most noticeably affected being: the antennae, the number of the joints in the flagella increasing and the proportions of the peduncle joints altering with growth; the second gnathopods, the hand of which increases in size and alters in shape to a far greater degree than the hand of the first gnathopod; and the chitinous cuticle of the body, spinose processes developing, and growing longer, more acute, and more numerous with age. An example of the development of the processes of the cuticle, bearing on the present case, will be found in the paper above referred to (p. 870), where the stages of growth in one species were traced; the cuticle in the very young animal was perfectly smooth, the spinose processes commencing as slight swellings, and developing at maturity into rounded upstanding tubercles, only assuming their characteristic shape with the further development of the animal.

It will be seen that the distinguishing points given by Norman to differentiate his species from Bruzelius's are precisely those which would be influenced by age and growth. With regard to the first. point-the stronger armature of the body-I found on examining the specimen of tuberculatus that the tubercles are of exactly the same number and arranged in exactly the same manner as the spineprocesses of armatus, those on the last peraeon-segment and the first. two pleon-segments being larger than the others, as Norman noted in armatus. The 1st segment has two, one behind the other; the 2nd segment three, one median in front of the transverse furrow, followed by two side by side; the remaining peraeon-segments and two first. pleon-segments each have a swelling in front of the furrow, with two. tubercles side by side behind. This agrees with Bruzelius's description; * he states (p. 11) that the 2 nd, 3rd, 4th, and 5 th segments. carry three tubercles each, one in front of the other two; but, except on the 2nd segment, as described above, the anterior tubercle is not. distinctly defined. Boeck's account is the same. Sars, however,

" “Tvärs öfver dess ryggsida går en intryckning, och på ryggen bär det två små knölar. Det andra, tredje, fjerde och femte segmentet hafva, liksom det första, en tvärs öfverryggen gående intryckning, och tre små knölar, den ena framför de två andra. . . . Det sjette och sjunde segmentet, som äro hopvuxna med hvarandra, hafva på ryggen två par knölar. Deras epimerer äro åtskilda. De tre första abdominal-segmenterna äro korta, och af dessa bära de två första två knölar på ryggen." Bruz. (p. 11). 
appears to have had younger specimens to deal with than either Bruzelius or Boeck. His description (p. 630) is as follows: "1st segment with two succeeding dorsal tubercles; 2nd segment with a slight tubercle in front of the sulcus; the succeeding segments scarcely tubercular, but having the dorsal contour somewhat rugged."

There is little to add to the full descriptions of the species, already referred to. In both specimens the 6 th and 7 th peraeon-segments are coalesced; the finger of Gnathopod 1 is bifid at the apex and furnished on both margins with small setae; the finger of Gnathopod 2 has the marginal setae as in Gnath. 1, and two specialized bristles at the articulation, one simple and one plumose; the pleopods have no cleft spines; the coupling-spines are of the same construction as those figured by Stebbing for L. purus (39), pl. 132, six in the older animal (armatus), and rami 9-jointed, five coupling-spines in tuberculatus and rami 8-jointed.

The species has only been recorded hitherto from the coast of Norway and the Shetland Islands.

\section{Tribe CYAMidea. Stebbing (42), p. 464.}

\section{FAM, CAPRELLIDAE.}

GEN. Pseudoprotella, Mayer.

Pseudoprotella phasma (Montagu).

(For synonymy and distribution, see Mayer (19), p. 29 ; (20), p. 19 ; and (21), p. 37.)

Station XIII. Five specimens; 1 female measuring $11 \mathrm{~mm}$, and 4 males, $10-15 \mathrm{~mm}$. in length.

This species has been frequently taken on the oceanic coast of France, but the depth at which the Huxley specimens were trawled, 412 fathoms, appears to be the greatest yet recorded for its occurrence.

GEN. Pariambus, Stebbing (39), p. 1268.

Pariambus typicus (Kröyer).

(See Mayer, Podalirius typicus (19), p. 75; (20), p. 92; and (21), p. 63.)

Station V. One specimen, a female with ova, measuring $3 \mathrm{~mm}$. , depth 109 fathoms.

Recorded from the Bay of Biscay by Chevreux, found on Maia, Asterias, etc. 


\section{Tribe PhronimideA, Stebbing (42), p. 473.}

\section{FAM. VIBILIIDAE.}

GEN. Vibilia, Milne Edwards.

Vibilia armata, Bovallius.

Station VIII. Surface: 1 specimen, a female, measuring $10 \mathrm{~mm}$.

Recorded before from the Bay of Biscay by Stebbing (40), p. 31.

\section{FAM. HYPERIIDAE.}

\section{Gen. Hyperia Latreille.}

\section{Hyperia galba (Montagu).}

Station X. Seven specimens. The largest, a female carrying eggs, measured $23 \mathrm{~mm}$.; of the others 2 were ovigerous females, $16 \mathrm{~mm}$.; 1 a large male, $14 \mathrm{~mm}$. ; the three remaining, 1 male and 2 females, were immature, the smallest $5.5 \mathrm{~mm}$. in length.

\section{Gen. Euthemisto, Bovallius.}

\section{Euthemisto compressa (Goës).}

All the specimens were acutely carinate dorsally, but in many (cf. also the specimen described by Stebbing (40), p. 38) the projecting dorsal teeth were not developed.

Station IV. Ten specimens; 7 ovigerous females, the largest $5.5 \mathrm{~mm}$. long, 1 young male, and 2 adult males, $5 \mathrm{~mm}$.

Station X. 42 specimens; 36 females and 6 males; the largest measured $7 \mathrm{~mm}$.

I agree with Tattersall (43), p. 36, in considering $E$. gracilipes Norman as a young stage of E.compressa. Both forms have been recorded from the Western Stations by the Int. Council Investigations.

\section{Euthemisto bispinosa (Boeck).}

Station X. Two specimens; ovigerous females, the larger $8 \mathrm{~mm}$. in length; the dorsal spinose processes not much developed in either.

With this record it will be interesting to compare a haul made on May 16,1909 , by the Huxley, not far from Station X., in $47^{\circ} 47^{\prime} \mathrm{N}$., $7^{\circ} 44^{\prime}$ W., when the tow-nets were choked with an immense swarm of large specimens of this species. In this haul the females outnumbered the males by three to one. They were much larger on the average, the largest females in the sample examined by me measuring $31 \mathrm{~mm}$. from 
rostrum to tip of uropods, while the largest males were only $18-19 \mathrm{~mm}$. There were only a very few small ones, and of these the smallest was $9 \mathrm{~mm}$. long. The two specimens from Station $\mathrm{X}$ agree in all structural details with these large ones, the only difference being the degree of development of the dorsal processes on the two last peraeon-segments and the two first pleon-segments, which in the larger specimens are greatly produced. The variation in size is not confined to this species. Stebbing has noted a similar case in Parathemisto oblivia (40), p. 37 ; and it was one of Norman's principal reasons for separating $E$. gracilipes from $E$. compressa (27), p. 54 .

The pouches of all the females (May, 1909) were greatly distended with either young just hatched or with eggs nearly hatched. Owing to the extrusion of most of the contents of the pouches it was impossible to estimate the number carried by any one female. It must, however, be considerable; one female, $20 \mathrm{~mm}$. long, had 71 young, each measuring $1.5 \mathrm{~mm}$., still remaining in the pouch. In view of Sars's remarks as to the peculiar armature of the 6 th joint of the $3 \mathrm{rd}$ peraeopod forming a constant specific character in the very young specimen equally with the adult, it may be worth while to note here that in the larval E. bispinosa all five peraeopods are practically subequal in length, and the 3rd is not distinguishable from the others. The proportions of the joints are quite different also, e.g. the finger of the 3rd peraeopod is nearly as long as the preceding joint.

\section{FAM. LYCAEIDAF.}

\section{Gen. Brachyscelus, Bate.}

\section{Brachyscelus crusculum, Sp. Bate.}

Station X. One specimen, an ovigerous female, $8.5 \mathrm{~mm}$. long. "XII. One specimen, a large ovigerous female, $17 \cdot 5 \mathrm{~mm}$.

For the discussion as to the identity of Thamyris mediterranea Claus with Brachyscelus crusculum Sp. Bate, see Norman (26), p. 134; Tattersall (43), p. 26 ; and Stebbing (40), p. 41. I have not seen any males of this species, but an examination of the two female specimens mentioned above would seem to support Norman's view that T. mediterranea is only a young stage of $B$. crusculum. In the small female the 3rd uropods reach to nearly the level of the telson, as in Senna's figure 10 (33), p. 8, while in the large female the telson extends considerably beyond them, as in Chevreux's figure 8 (11), p. 74 . 
LIST OF SPECIES, AND THE STATIONS AT WHICH THEY OCCURRED.

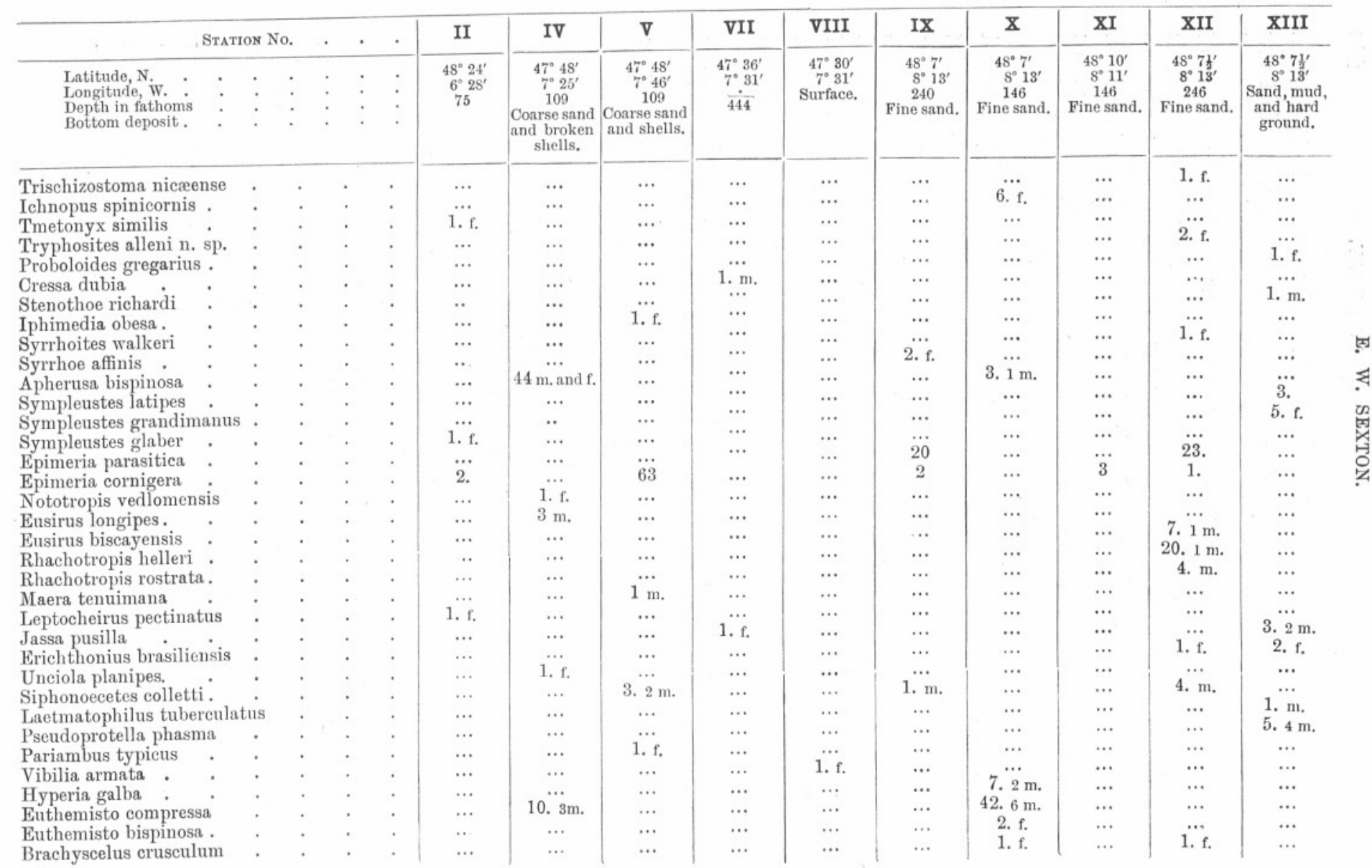




\section{BIBLIOGRAPHY.}

1 Bate, C. Spence. On the Morphology of some Amphipoda of the Division Hyperina. Ann. Mag. Nat. Hist. (3), v. 8. 1861.

2 Bate, C. Spence. Catalogue of the Specimens of Amphipodous Crustacea in the Collection of the British Museum. 1862.

3 Bate and Westwood. British Sessile-eyed Crustacea. 1862.

4 Вовск, Axel. De Skandinaviske og Arktiske Amphipoder. Christiania, $1872-6$.

5 Bonsier, J. - Catalogue des Crustacés malacostracés recueillis dans la baie de Concarneau. Bull. Scient. du Départ. du Nord, v. 18. Paris, 1887.

6 Bonnier, J. Edriophthalmes. Rés. Scient. Campagne du Caudan. Ann. Univ. Lyon. 1896.

7 Bovallius, C. Contributions to a Monograph of the Amphipoda Hyperiidea. Pts. 1 and 2. 1887-9.

8 Bruzelius, R. Bidrag till Kännedomen om Skandinaviens Amphipoda Gammaridea. Lund, 1859.

9 Chevreux, E. Catalogue des Crustacés amph. marins du S.-O. de la Bretagne. Bull. Soc. Zool. France, T. xII. 1887.

10 Chevreux et Bouvier. Les Amphipodes de Saint-Vaast-la-Hougue. Ann. Sc. Nat. Zool. ser. 7. v. xv. 1893.

11 Chevreux, E. Sur les Crustacés recueillis dans l'estomae des Germons. Bull. Soc. Zool. France, v. xvIII. 1893.

12 Chevreux, E. Les Amphipodes des premières campagnes de la PrincesseAlice. Mém. Soc. Zool. France, T. viII. Paris, 1895.

13 Chevreux, E. Révision des Amphipodes de la côte océanique de France. Assoc. Franç. avanc. Sciences. Congrès de Nantes, 1898.

14 Chevreux, E. Amphipodes provenant des campagnes de l'Hirondelle. Monaco. 1900.

15 Chevreux, E. Description d'un Amphipode, etc. Bull. Mus. Ocean. Monaco, No. 35. Mai, 1905.

16 Chevreux, E. Diagnoses d'Amphipodes nouveaux, etc. Bull. Inst. Océan. Monaco, No. 129. 1908.

17 Fowler, G. H. Contributions to our knowledge of the Plankton of the Faroe Channel. No. virr. Proc. Zool. Soc., London, 1903, v. 1.

18 Jeffreys and Norman. Submarine Cable Fauna. Ann. Mag. Nat. Hist. (4) v. 15. 1875.

19 Mayer, P. Die Caprelliden des Golfes von Neapel. Fauna u. Flora des Golfes v. Neapel. Mon. 6. 1882.

20 Marer, P. Die Caprelliden des Golfes v. Neapel. Nachtrag. Mon. 17. 1890.

21 Mayer, P. Die Caprelliden der Siboga-Expedition. Leiden. 1903.

22 Montagu, G. Description of several Marine Animals found on the South Coast of Devonshire. Trans. Linn. Soc., v. 9. 1808. 
23 Nebeski, O. Beiträge zur Kenntniss der Amphipoden der Adria. Arbeit. Zool. Inst. Wien. T. 3. H. 2. 1880.

24 Norman, A. M. On Crustacea Amphipoda new to Science or to Britain. Ann. and Mag. Nat. Hist. (4), v. 2. 1868.

25 Norman, A. M. Last Report on Dredging among the Shetland Isles. Pt. II. Brit. Assoc. Advanc. Science. Report for 1868. 1869.

25a Norman, A. M. A Month on the Trondhjem Fiord. Ann. Mag. Nat. Hist. (6), v. 15.1895.

26 Norman, A. M. British Amphipoda of the Tribe Hyperiidea, etc. Ann. Mag. Nat. Hist. (7), vol. 5. 1900.

27 Norman and Scotr. The Crustacea of Devon and Cornwall. London, 1906.

28 Robertson, D. A second contribution towards a Catalogue of the Amphipoda and Isopoda of the Firth of Clyde and West of Scotland. Nat. Hist. Soc. Glasgow, 1892.

29 Sars, G. O. Oversigt af Norges Crustaceer. Christ. Vidensk.-Selsk. Forhandl. 1882. No. 18.

30 SARs, G. O. An account of the Crustacea of Norway, v. 1, Amphipoda, 1894.

31 Sars, M. Overs. Norg. Arkt. Krebsd. Christ. Vidensk.-Selsk. Forhandl., f. 1858.1859.

32 Sсотт, T. Report on the Marine and Freshwater Crustacea from FranzJosef Land. Journ. Linn. Soc., v. 27, 1899.

32a Scotr, T. Additions to the Fauna of the Firth of Forth. Pt. VIII. Fourteenth Annual Report of the Fishery Board for Scotland. 1896.

33 Senna, A. Su Alcuni Anfipodi iperini del Museo Zoologico di Napoli. Ann. Mus. Zool. Univ. Napoli., N.S., v. 1, No. 6. 1903.

34 Sexton, E. W. On the Amphipod genus Trischizostoma. Proc. Zool. Soc., London, September, 1908.

35 Sexton, E. W. Notes on some Amphipoda from the North side of the Bay of Biscay. Families Pleustidae and Eusiridae. Proc. Zool. Soc., April, 1909.

36 Sexton, E. W. On the Amphipod genus Leptocheirus. Proc. Zool. Soc., Pt. III, 1911.

37 Sex̃ton, E. W. A new Amphipod Species, Tryphosites alleni. Ann. Mag. Nat. Hist., Ser. 8, Vol. VII, May, 1911.

38 Stebbing, T. R. R. On some new and little-known Amphipodous Crustacea. Ann. Mag. Nat. Hist. (4), v. 18. 1876.

39 Stebbing, T. R. R. Challenger Reports, vol. 29, Amphipoda. 1888.

40 Stebing, T. R. R. Biscayan Plankton collected during a cruise of H.M.S. Research, 1900, Pt. II. The Amphipoda and Cladocera. Trans. Linn. Soc., London, ser. 2, v. 10, pt. 2.1904.

41 Stebbing, T. R. R. Das Tierreich, 21 Lief. Amphipoda I. Gamma. ridea. Berlin, 1906.

42 Stebing, T. R. R. General Catalogue of the South African Crustacea. Ann. S. African Museum, v. VI, pt. 4. 1910. 

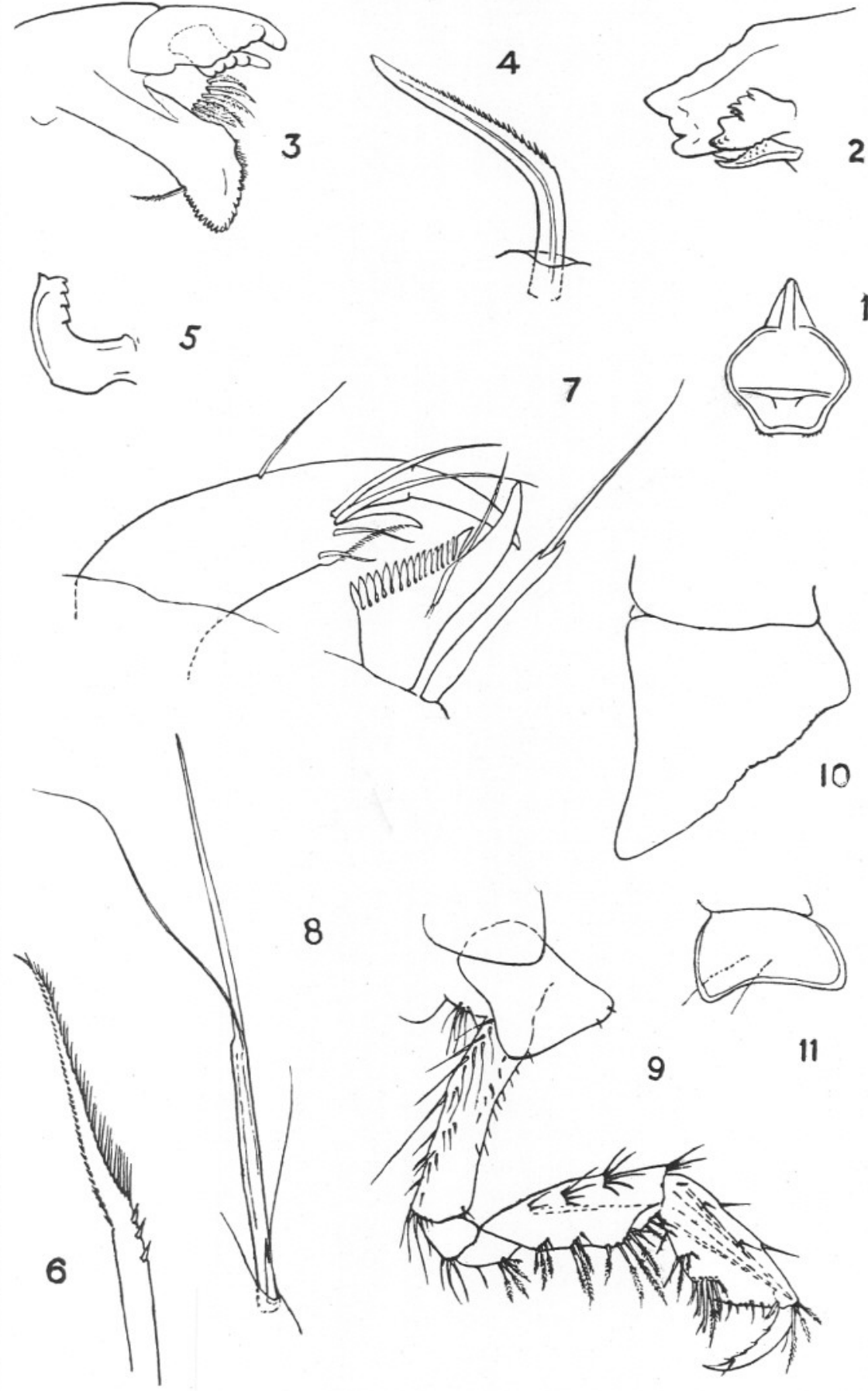

8

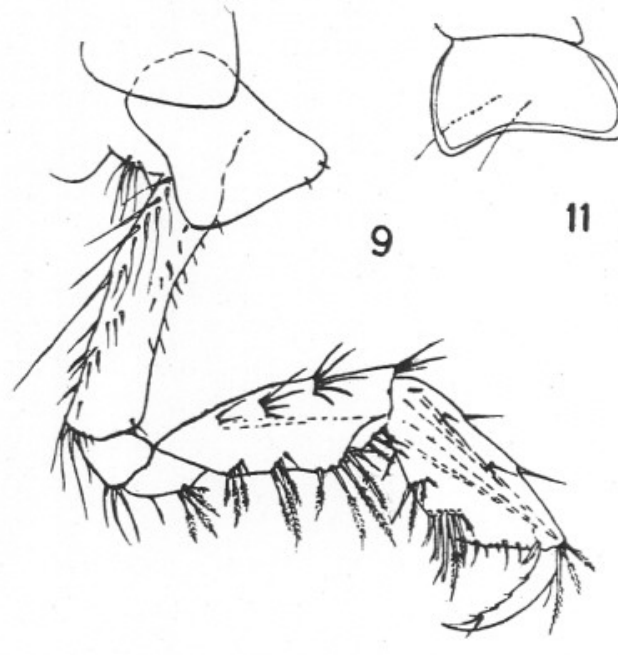

EWSexton del. 
43 Tattersali, W. M. Pelagic Amphipoda of the Irish Atlantic Slope. Fish. Ireland Scient. Invest., 1905, No. 4. 1906.

44 Walker, A. O. The Amphipoda of Bate and Westwood's "British Sessile-eyed Crustacea." Ann. Mag. Nat. Hist. (6), v. 15. 1895.

45 WALKer, A. O. Revision of the Amphipoda of the L.M.B.C. district. Trans. Liverp. Biol. Soc., v. IX. 1895.

46 Walker, A. O. Crustacea collected by the late Mr. R. L. Ascroft and Mr. Harvey in the North of the Bay of Biscay. Ann. Mag. Nat. Hist. (8), v. 5, February, 1910.

\section{EXPLANATION OF PLATE III.}

Fig. 1. Upper Lip . . . Syrrhoe affinis Chevreux $\mathrm{x} 42$

" 2. Cutting plate, accessory plate, and spine. Right mandible

Syrrhoe affinis Chevreux x145

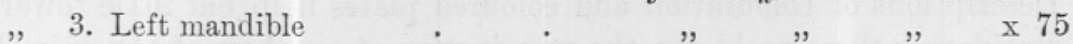

" 4. Curved spine, inner plate, Maxillipeds " ", " " $\quad$ ", x435

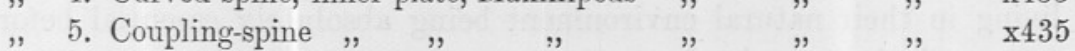

" 6. Bristle from joint 5, gnathopod 1 $\quad$ " $\quad ", \quad ", \quad$ "

, 7. Finger and palmar spine, upper surface, gnathopod 2

Syrrhoe affinis Chevreux $\mathrm{x} 380$

" 8 . Sensory spines from distal end of joint 6 , peraeopod 3

Syrrhoe affinis Chevreux $\mathrm{x} 265$

" 9. Gnathopod 1, ovigerous female Apherusa bispinosa (Bate) × 75

"10. Sideplate 2, adult male, $11 \mathrm{~mm}$. long

$\begin{array}{lll}\text { Jassa falcata (Montagu) } & \mathbf{x}\end{array}$

"11. Sideplate 2, adult male, 5.5 mm. long Jassa pusilla (Sars) $\times 42$ 